\title{
History and promotion of a culture of peace at global level through education
}

\author{
Kunal Mehta \\ LR DAV College Jagraon, India
}

Email: professorkunal@yahoo.com

\begin{abstract}
This article is concerned with the great task before the United Nations: saving future generations from the scourge of war. This entails the transformation not only of the institutional structures and manifestations of war, but also of the deeply rooted culture of violence and war, and the evolution of a culture of peace and non-violence. It provides a brief history of the concept of the culture of peace, discusses the basic aspects of the concept, and reflects on its relationship with everyday life. It then outlines the various actions undertaken by UNESCO during 1992-8 to promote a culture of peace, and lists declarations for a culture of peace and non-violence.
\end{abstract}

Keywords: History, Promotion, Culture, Peace, Education

\section{Introduction}

The United Nations is challenged to take up with renewed commitment and resources its fundamental task: to save future generations from the scourge of war. This task requires transforming not only the institutional structures and manifestations of war, but also its deep cultural roots, the culture of violence and war, into a culture of peace and non-violence. The transition from the 
culture of war to a culture of peace, initially taken up as a priority by the United Nations Educational, Scientific and Cultural Organization (UNESCO), has now been taken up by the United Nations as well. Three points may be made by way of summary. First, a culture of peace: consists of values, attitudes, and behaviors that reflect and inspire social interaction and sharing, based on the principles of freedom, justice, and democracy, all human rights, tolerance and solidarity, that reject violence, endeavor to prevent conflicts by tackling their root causes to solve problems through dialogue and negotiation and that guarantee the full exercise of all rights, and the means to participate fully in the development process of their society. Second, violence is not inevitable. Third, rather than intervening in violent conflicts after they have erupted and then engaging in post-conflict peace building, it is more humane and more efficient to prevent such violence in the first place by addressing its roots: this is the essence of a culture of peace approach. The creation of the United Nations system based on universally shared values and goals has been per se a major act of a culture of peace. The international instruments adopted under its auspices and the declarations and action plans of its recent world conferences reflect the development and deepening of commonly shared norms, values, and aims that may be considered as the core of the evolving concept of a culture of peace. These norms, values, and aims constitute the basis of a global ethics and show that fundamentally many of the most important values are common to all great moral traditions and that there is no sharp cleavage between values of various groups of countries, between the North and the South, the East and the West. In a rapidly and deeply changing world characterized by the growing importance of ethical issues, a culture of peace provides future generations with values that can help them to shape their destiny and actively participate in constructing a more just, humane, free, and prosperous society, and a more peaceful world. The General Assembly of the United Nations, in proclaiming the Year 2000, at the turn of the millennium, as the International Year for the Culture of Peace, and the decade 2001-10 as the International Decade for a Culture of Peace and Non-Violence for the Children of the World, has recognized the importance of mobilizing public opinion for a culture of peace.

\section{A Brief History of the Culture of Peace Concept}

The concept of a culture of peace arose at the end of the Cold War. For the first time, the objective for which the United Nations was founded, the abolition of war, had become feasible. The culture of peace concept was 
developed in 1992 at UNESCO as the Organization's response to "An Agenda for Peace" at the United Nations Security Council.

It had first been proposed in the Declaration of Yamoussoukro (Côte D'Ivoire) in 1989. Reasoning that peacekeeping operations alone might assure the absence of war but could not by themselves bring a positive, dynamic peace, UNESCO argued that this could be done best by engaging those who had been in conflict in common ventures of human development. Acting primarily in the fields of education, science, culture, and communication, UNESCO offered its services in "post-conflict peace building." Projects were undertaken in a number of countries of Central America, Africa, as well as in collaboration with the government of the Philippines. A comprehensive overview of the culture of peace at this early stage is contained in the monograph, UNESCO and a Culture of Peace: Building a Global Movement. The transition from the culture of war to a culture of peace was taken up as a priority by the twenty-eighth session of the General Conference of UNESCO in 1995. Having considered the initial experiences of the Culture of Peace Programme that it had established in 1993, the General Conference declared that this transition was the greatest challenge facing the world at the end of the twentieth century and dedicated UNESCO's Medium-Term Strategy for 1996-2001 to its promotion.

This was seen as the contemporary expression of the Constitutional mandate of UNESCO which declares that peace requires more than political and economic arrangements of governments; peace must be founded on the intellectual and moral solidarity of humankind. In December 1995, the United Nations General Assembly placed a culture of peace on its agenda for the first time by adopting resolution 50/173, welcoming with appreciation the resolution concerning a culture of peace recently adopted by the UNESCO General Conference. It requested the Secretary-General, in consultation with the Director General of UNESCO, to report to its fifty-first session regarding progress of educational activities in the framework of the interdisciplinary project entitled "Towards a Culture of Peace." Further, having received and welcomed the said report, the fifty-first session of the General Assembly in its resolution 51/101 requested the Secretary- General, in coordination with the Director- General of UNESCO, to report to its fifty- second session on the progress of educational activities within the framework of the transdisciplinary project entitled "Towards a Culture of Peace," including the preparation of elements for a draft provisional declaration and program of action on a culture of peace. The UNESCO transdisciplinary project "Towards a Culture of Peace" 
was revised and strengthened by the twenty-ninth General Conference in October 1997. The framework of this project has three main lines of activity:

- Education and training for peace, human rights, democracy, tolerance, and international understanding, including elaboration and dissemination of teaching materials and pedagogical aids in different languages.

- Policy-oriented research, advocacy action, and exchange and dissemination of information.

- Capacity-building and technical support for national, sub regional, regional, and international projects.

Having received the elements for a draft provisional declaration and program of action on a culture of peace (A52/292), the fifty-second session of the United Nations General Assembly, in November 1997, requested the SecretaryGeneral, in co- ordination with the Director-General of UNESCO, to submit a consolidated report containing a draft declaration and program of action on a culture of peace to the General Assembly at its fifty-third session, which is the origin of the present document. At the same time, in November 1997, the General Assembly proclaimed the year 2000 as the International Year for the Culture of Peace. One year later, the General Assembly further proclaimed the decade 2001-10 as the International Decade for a Culture of Peace and NonViolence for the Children of the World. The development of the concept of the culture of peace, therefore, has both theoretical and practical value. It provides a conceptual framework that emphasizes the importance of addressing the deep cultural roots of war and violence, and it constitutes the basis for a coherent strategy for a transformation to a culture of peace and non-violence.

\section{Basic Aspects of the Culture of Peace}

As indicated in resolution 52/13 of the United Nations General Assembly, seven major aspects of a culture of peace may be distinguished: human rights, democracy, tolerance, promotion of development, education for peace, the free flow of information, and the wider participation of women. For each aspect, actions are needed to transform a set of values, attitudes, and behaviors of individuals, collectives, and institutions that are fundamental to the culture of war and violence.

\section{Human Rights}

The elaboration and international acceptance of universal human rights, 
especially the Universal Declaration of Human Rights, has been one of the most important steps towards the transition from a culture of war and violence to a culture of peace and nonviolence. It calls for a transformation of values, attitudes, and behaviors from those that would benefit one group exclusivelythe clan, the tribe or the nation-towards those that benefit the entire human family. Hence, the promotion of human rights at both individual and collective levels is at the heart of actions to promote a culture of peace and non-violence.

\section{Democracy}

The fostering of democratic participation and governance is essential for the development of a culture of peace and non-violence. This is the only way to replace the authoritarian structures of power which were created by, and which have in the past sustained, the culture of war and violence. As stated by the Copenhagen Declaration on Social Development:

Democracy and transparent and accountable governance and administration in all sectors of society are indispensable foundations for the realization of social and people centered sustainable development [which, with social justice] are indispensable for the achievement and maintenance of peace and security within and among our nations.

\section{Tolerance}

There has never been a war without an "enemy," and to abolish war, we must transcend and supersede enemy images with understanding, tolerance, and solidarity among all peoples and cultures. Only by celebrating the tapestry of our diversity, the common threads of human aspiration and social solidarity that bind us together, and by ensuring justice and security for everyone who makes up the warp and woof of the cloth, can we truly affirm that we are weaving a culture of peace. Therefore, a renewed commitment is needed to the actions proposed by the Declaration of Principles on Tolerance (Paris, 1995) and other actions that promote "intellectual and moral solidarity" which, as declared by the UNESCO Constitution, is the only secure basis for peace.

\section{Promotion of Development}

It is increasingly recognized that in the long term, everyone gains from the implementation of sustainable human development for all. The poverty and exclusion of some increases the vulnerability of all. This represents a major change in the concept of economic growth which, in the past, could 
be considered as benefiting from military supremacy and structural violence and achieved at the expense of the vanquished and the weak. As declared by the World Summit for Social Development (Copenhagen, 1995), social development, social justice, and the eradication of poverty are indispensable for the achievement and maintenance of peace and security within and among our nations. In turn, these cannot be attained in the absence of peace and security or in the absence of respect for all human rights and fundamental freedoms. As stated in the proposals of the United Nations Development Programme (UNDP), people-centered development is both a precondition for peace and the consequence of peace.

\section{Education for Peace}

Education is the principal means of promoting a culture of peace. This includes not only formal education in schools, but also informal and non-formal education in the full range of social institutions, including the family and the media. The very concept of power needs to be transformed: from the logic of force and fear, to the force of reason and love. Education should be expanded so that basic literacy is joined by the "second literacy" of "learning to live together." A global effort of education and training, supported by the United Nations, should empower people at all levels with the peacemaking skills of dialogue, mediation, conflict transformation, consensus-building, co-operation, and nonviolent social change. This campaign should be based upon universal principles of human rights, democratic principles, and social justice, and at the same time, build upon the unique peace-making traditions and experiences of each society. It should be linked with other campaigns already launched on regional and national levels, such as the initiative for education for democratic citizenship of the Council of Europe.

\section{The Free Flow of Information}

Freedom of opinion, expression, and information, recognized as an integral aspect of human rights and fundamental freedoms, is a vital factor in the strengthening of peace and international understanding. It is needed to replace the secrecy and manipulation of information that characterize the culture of war. In this regard, the media can be a powerful partner for the construction of a culture of peace. Its technological advances and pervasive growth have made it possible for every person to take part in the making of history, enabling for the first time a truly global movement for a culture of 
peace. At the same time, however, the media is sometimes misused to create and disseminate enemy images, violence, and even genocide against other ethnic and national groups, and to portray and glorify violence in many forms. Also secrecy is on the increase, justified in terms of "national security" and "economic competitiveness," whereas in fact more transparency is needed in governance and economic decision-making. Therefore, actions are proposed in support of this aim that realize the positive potential of the media to provide essential information and to promote, via participatory communication, the values, attitudes, and behaviors of a culture of peace.

\section{Wider Participation of Women}

As recognized by the Fourth World Conference on Women (Beijing, 1995), there is an inextricable linkage of peace with equality between women and men. Only this linkage of equality, development, and peace can replace the historical inequality between men and women that has always characterized the culture of war and violence. As pointed out at the Conference, it is necessary to promote women's political and economic empowerment and equal representation at every level of decision- making so that women's experience, talents, visions, and potential can make their full contribution to a culture of peace. The analysis is becoming generally accepted in the world today that women themselves have always been anti-war and against violence in view of their roles as mothers and wives, and in times of conflict, women and children have always been the victims. The foundations for an enduring and sustainable culture of peace require the full integration of women at all levels of the decision-making processes including the political arena, peace-building, and resolution and prevention of conflicts. The culture of peace, as defined by the United Nations General Assembly, does not include those aspects of peace and security that are the domain of the United Nations Security Council. However, actions that promote the one may be synergistic and mutually reinforcing to actions that promote the other. International peace, in the sense of the absence of war and the presence of security between nations, is a necessary condition for the full establishment of a culture of peace. At the same time, however, only the establishment of a culture of peace can provide an effective basis for the prevention of war and violence and the ensuring of long-term security. Therefore, actions to promote a culture of peace need to be co-ordinated with those to promote international peace and security, such as peace diplomacy, peacekeeping, disarmament, and military conversion. 


\section{Bibliography}

This article is adapted and updated from the report on a culture of peace developed by the United Nations Educational, Scientific and Cultural Organization (UNESCO) for the United Nations General Assembly in 1998 (document $\mathrm{A} / 53 / 370$ ). Other invaluable resources include:

- Records of the Twenty-Eighth General Conference of the United Nations Educational, Scientific and Cultural Organization (1995) Vol. 1 Resolution 0.12, Medium-Term Strategy for 1996- 2001.

- The Seville Statement on Violence, UNESCO, 1991.

- Resolution of the United Nations General Assembly A/RES/52/15, Proclamation of the year 2000 as the International Year for the Culture of Peace, adopted on November 20 1997, recalling Economic and Social Council Resolution 1997/47 of July 22 1997, Final report.

- International Congress on Peace in the Minds of Men, June 26-July 1 1989, Yamoussoukro, Côte d'Ivoire, UNESCO; UNESCO and a Culture of Peace: Promoting a Global Movement. 1995. Revised and reprinted in Cultures of Peace Series (UNESCO 1997).

- Preamble of the Constitution of the United Nations Educational, Scientific and Cultural Organization.

- The Copenhagen Declaration, World Summit for Social Development, articles 4 and 5 .

- The Copenhagen Declaration, op. cit., article 5. The World Declaration on Education for All (Jomtien, 1990), UNESCO, 1990.

- Learning: The Treasure Within, report submitted to UNESCO by the International Commission on Education for the Twenty-first Century (UNESCO, 1996)

- Universal Declaration of Human Rights, article 19. Report of the Fourth World Conference on Women (Beijing, September 4-15 1995), Annex II, Platform for Action, para. 131. 